\title{
Aboriginal Forestry News / Nouvelles dans le domaine de la foresterie autochtone
}

\section{National Conference on Aboriginal Forestry}

\section{Creating a New Climate for Aboriginal Forestry \\ Thunder Bay Ontario May 1 1-13, 2004}

The First Nations Forestry Program convened the National Conference on Aboriginal Forestry in Thunder Bay May 11-13, and by all accounts it was a resounding success. Over 300 delegates from across Canada registered for the event, which was held at the Airlane Travelodge Hotel.

The proceedings were opened with ceremonial drumming and a Native prayer. Elders and a representative of the traditional Fort William First Nation territory extended a ceremonial welcome and offered their best wishes to the delegates for a productive conference. As well, Lynn Peterson, Mayor of Thunder Bay, Nelson Toulouse, Deputy Grand Chief, Anishinabeck Nation - Union of Ontario Indians and Brian Wilson of Natural Resouces Canada, Ross Barclay of Indian and Northern Affairs Canada and Harry Bombay of the National Aboriginal Forestry Association, these three representing the National Advisory Council of the First Nations Forestry Program.

The keynote address to begin the program was given by Charles Fox, Ontario Regional Chief, and Chiefs of Ontario. The three-day event included plenary sessions at the start of each day after which concurrent workshops were conducted that focused on four daily themes. These dealt with issues such as technical, legal and cultural aspects of forest resource management in both conventional and non-traditional purviews.

Special side trips were made to Confederation College to examine the forestry technician program offered there and new linkages to the Forestry degree program offered at Lakehead University. Evening sessions were included at Fort William Historic Park and at the Fort William First Nation Community Centre. Meals at each were themed to the colourful history of the North West Company and the traditions of the people of the Fort William First Nation.

Organizers are pleased to have secured letters of commendation from The Right

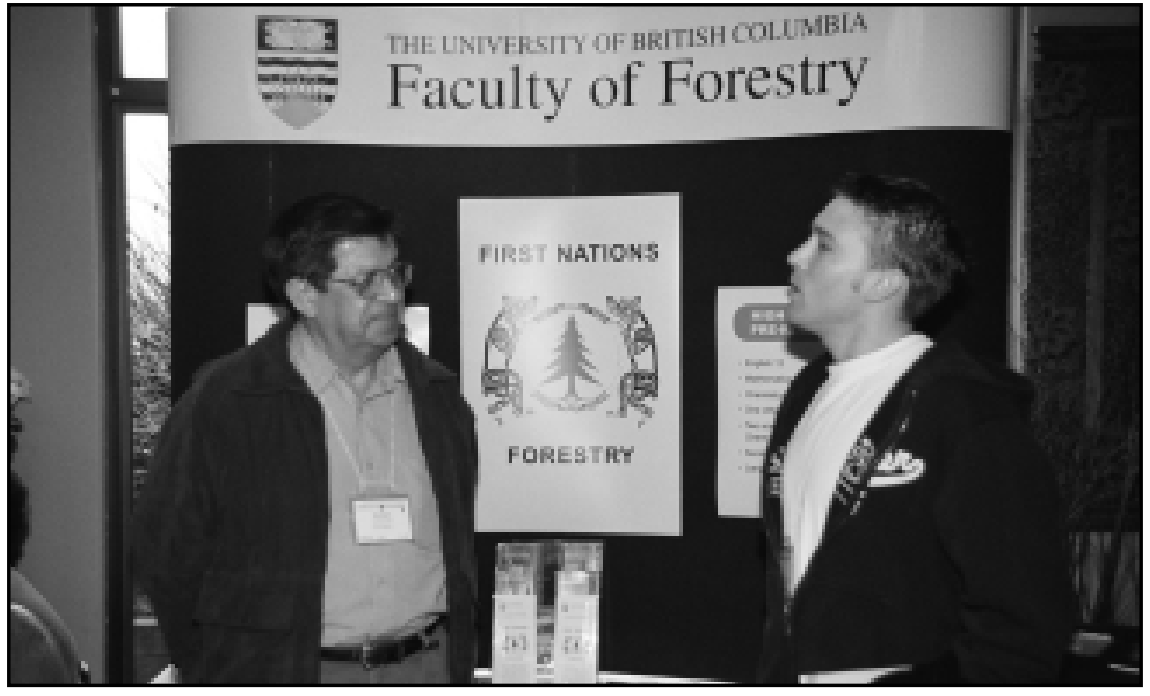

Gordon Prest of the Stó:lô Nation, BC and Co-ordinator for First Nations Forestry and Conservation Initiatives, Faculty of Forestry, UBC speaking with a conference delegate.

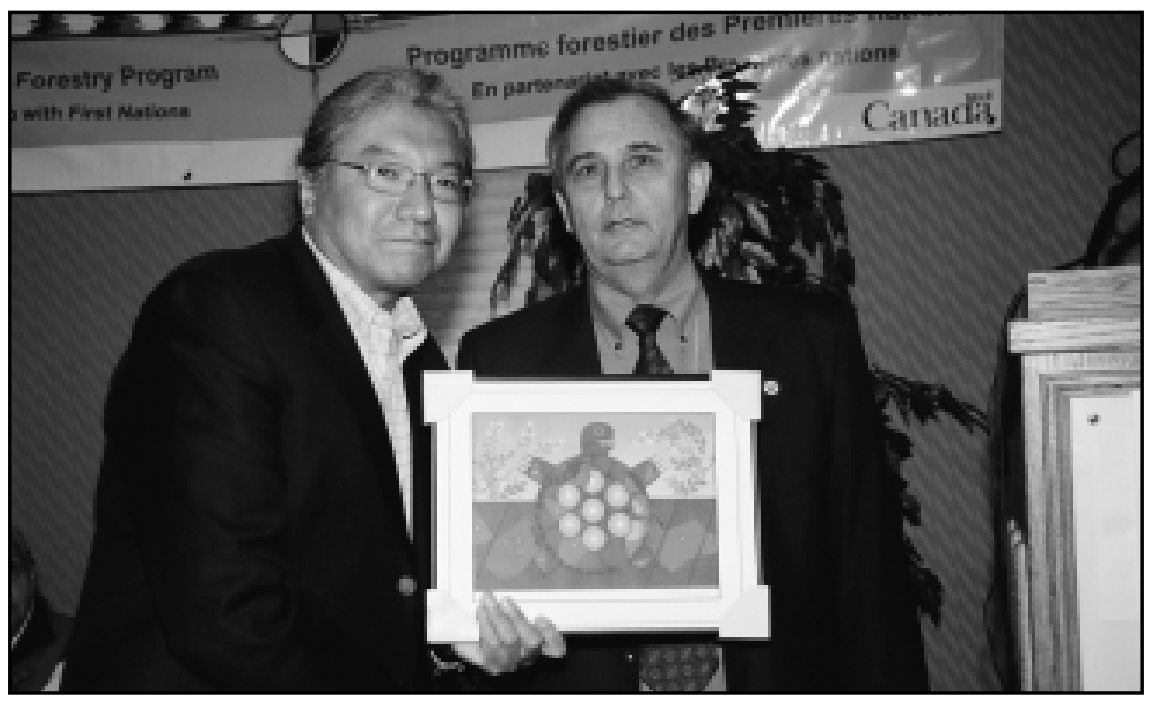

Keynote Speaker Charles Fox, Ontario Regional Chief, Chiefs of Ontario accepting a token of appreciation from Jack Smyth, Manager, Forestry Development and Aboriginal Affairs, First Nations Forestry Program, Canadian Forest Service, NRCan.

Honourable Paul Martin, Prime Minister of Canada, The Honourable John Efford, Minister of Natural Resources, The Honourable Andrew Mitchell, Minister of Indian and Northern Affairs and James K. Bartleman, Lieutenant Governor of Ontario.

Proceedings of the Conference are posted on the web site of the National Conference on Aboriginal Forestry www.aboriginalforestry.org.
For further Information:

Dave Lemkay

A/Manager Programs Outreach Industry, Economics and

Programs Branch

Canadian Forest Service Natural Resources Canada 


\section{Supreme Court Rulings Block Native Tax, Logging Appeals}

It was a disappointing day for aboriginal rights in the Supreme Court when western Canadian Cree and Dene lost a final bid for sweeping tax immunity and Eastern Canadian Mi'kmaq suffered a setback in their quest to cut and sell timber from Crown land. A three-judge panel refused to hear an appeal from Gordon Benoit, a heavy equipment operator from Fort McMurray, who wanted the bench to overturn a ruling that denied an estimated 30,000 aboriginals tax-free status based on their understanding of an 1899 treaty. On the other side of the country, the New Brunswick and Nova Scotia governments secured reviews of earlier decisions that gave the Mi'kmaq the right to harvest wood on Crown lands, rulings that could have enormous ramifications for forestry by forcing the industry to allow more aboriginal participation. By convention, the court gave no reason for its decisions. The Supreme Court's refusal to accept Benoit's appeal application puts an end to a 12-year legal battle that pitted Treaty 8 aboriginals - who are spread throughout 40 bands in Alberta, B.C., Saskatchewan and the Northwest Territories - against the federal tax collector and the provinces involved. "We place a lot of faith in the court system, but today's decision creates a bad taste in our mouths," said Grand Chief Archie Cyprien of the Treaty 8 First Nations of Alberta. "There were commitments and promises that were made." But the Canadian Taxpayers Federation hailed the ruling as "a great victory" for all Canadians who pay taxes. "Our federal and provincial legislatures can create legitimate tax exemptions to fight poverty, but tax exemptions should never be based on race or ancestry," said Tannis Fiss, a federation director. Two years ago, Federal Court Justice Douglas Campbell sparked an uproar when he awarded the Treaty 8 signatories tax immunity "at any time, for any reason" based on their ancestors' understanding of the deal. The Treaty 8 descendants argued the Crown had promised them an eternal tax exemption, ranging from income tax to GST and property tax, both on and off their reserves. Campbell's decision was overturned last summer in the Federal Court of Appeal.

In two other decisions, the Supreme Court accepted applications from New Brunswick and Nova Scotia to challenge ruling that confirmed that the Mi'kmaq had a treaty right to harvest and sell trees on Crown land that they traditionally occupied. In a decision last year, the New Brunswick Court of Appeal threw out a conviction against Joshua Bernard, of the Eel Ground First Nation near Miramichi, for illegally possessing Crown timber. The Supreme Court's decision to hear the appeal is a break for the New Brunswick government, which contends that it should be up to the Crown to control conservation of natural resources. The province's appeal court had given the government one year to reach a deal with the Mi'kmaq on how Crown lands would be harvested. Mi'kmaq loggers currently have only limited access to off-reserve timber. In the Nova Scotia appeal, Stephen Marshall Jr. and 34 other Mi'kmaq were cleared of illegally harvesting lumber when the province's appeal court ruled that historic rights to vast portions of woodlands in the province were confirmed in 18th-century treaties. The Supreme Court has already upheld the Mi'kmaq right to fish without a licence in a 1999 ruling that rocked the East Coast fishery.

\section{Accès des autoch La cour suprême du Canada entendra l'appel dans l'affaire Joshua Bernard}

La Cour suprême du Canada entendra l'appel de la province du NouveauBrunswick dans l'affaire Joshua Bernard. A l'enjeu, l'accès des autochtones aux forêts publiques du N.-B. La décision du plus haut tribunal au pays est tombée, hier. Pour le ministère de la Justice, il s'agit d'une bonne nouvelle. "Ca nous fait plaisir que la Cour suprême du Canada nous accorde l'autorisation de porter la décision en appel. On avait fait la demande et on est satisfait que la cause soit entendue", a indiqué Yassin Choukri, sous-ministre de la Justice.

Le N.-B. a interjeté appel à l' automne 2003 pour renverser la décision d'un tribunal néo-brunswickois qui a déclaré que les bûcherons autochtones ont des droits ancestraux leur permettant de couper et de vendre les arbres des terres publiques. Le Nouveau-Brunswick soutient que le jugement de la Cour d'appel

\section{tones aux forêts publiques du N.-B.}

est allé trop loin. 'Les points qu'on a interjeté en appel entourent l'interprétation du traité, mais les arguments comme tels seront présentés devant la Cour suprême du Canada lorsqu'on sera entendu", a précisé M. Choukri, qui a indiqué que la province devrait être entendue par la Cour suprême au printemps 2005. Selon le gouvernement, la conservation des ressources naturelles ne devrait relever que de la Couronne et non de groupes de personnes, qu'ils soient autochtones ou autres.

La Cour d'appel du Nouveau-Brunswick a statué en faveur du bûcheron micmac Joshua Bernard, de la réserve d'Eel Ground, en août 2003, mais elle a suspendu sa décision pour un an afin de donner le temps aux autorités provinciales de négocier l'accès aux terres publiques avec les autochtones. La décision de la Cour suprême, qui pourrait être rendue en 2005, risque d'avoir des conséquences majeures pour l'ensemble de l'industrie forestière canadienne. Elle pourrait la forcer à devoir composer avec les activités de coupe des autochtones, à l'instar des pêcheurs non autochtones qui doivent, depuis le jugement Marshall de la Cour suprême, en 1999, partager leurs activités avec leurs homologues amérindiens.

La cause de M. Bernard a débuté en 2000 lorsqu'il fut accusé de possession illégale de 23 troncs d'épinettes coupées sur des terres appartenant à l'État. Il a été reconnu coupable la même année. La Cour d'appel du Nouveau-Brunswick a ensuite renversé la décision, en 2003. Au N.-B., les autochtones des 15 réserves de la province n'ont accès qu'à $5 \%$ de l'ensemble des terres de l'Etat. La Cour suprême a aussi accepté de se pencher sur une requête de la Nouvelle-Écosse concernant là aussi un dossier autochtone relié à la coupe d'arbres. Le cas néo-écossais met en scène 35 bûcherons autochtones accusés en 1998 et 1999 d'avoir illégalement coupé des arbres. Ils ont été reconnus coupables en 2001. La Cour d'appel de la Nouvelle-Écosse a maintenu les verdicts, mais a ordonné un nouveau procès étant en désaccord avec les arguments avancés sur la question des droits des accusés. 


\section{Top Court Will Hear Provinces on Logging}

\section{New Brunswick, Nova Scotia challenge legality of natives' timber harvesting}

The Supreme Court of Canada has agreed to hear an appeal requested by the New Brunswick and Nova Scotia governments into two landmark native logging cases that could have implications for forestry in the rest of the country. New Brunswick contends a ruling last year by the province's Appeal Court on one of the cases went too far. "Our position is that there was an error in the interpretation of the treaty to extend itself to commercial logging rights," Yassin Choukri, the province's deputy attorney-general, said. "So hopefully the Supreme Court of Canada will listen to our position and will grant us our decision."

The New Brunswick case involves Mi'kmaq logger Joshua Bernard of the Eel Ground Reserve, convicted in 2000 of illegal possession of 23 spruce logs harvested from Crown land. The Appeal Court ruled that Bernard has a treaty right to harvest and sell trees growing on Crown lands that were historically occupied by native people. But Choukri said the conservation of natural resources should be the jurisdiction of the Crown and not "any one particular group of people, be it native or any other group who can unilaterally go on Crown lands and harvest for their own purposes." The Nova Scotia case involves 35 native loggers charged in 1998 and 1999 with illegally harvesting lumber and convicted in 2001. The Nova Scotia Appeal Court overturned the convictions but disagreed with the test of rights used during the original trial and sent it back for a new one. A decision in favour of the natives could have major implications for governments and the lumber industry.

Nova Scotia Justice Minister Michael Baker said Thursday there's a lot at stake. "Our position is there are no treaty rights that would have allowed those individuals who were charged to take wood on Crown land," he said. Bruce Wildsmith, a Nova Scotia native rights lawyer, said he's pleased the cases will be heard by the country's highest court. "It means that the Supreme Court, authors of the original Marshall decision, will get the opportunity to determine how to handle forests and trees," he said. Wildsmith said the issue of treaty rights for logging has been interpreted differently in each province. It will be at least a year before the Supreme Court will hear the appeal.

The validity of 18th-century treaties between the British and natives was a key element in the 1999 case of Donald Marshall, a Mi'kmaq eel fishermen in N.S.
The Supreme Court found that the treaties granted Mi'kmaq and Maliseet people the right to hunt, fish and gather for a moderate livelihood. The decision ultimately forced the East Coast fishery to allow more native access, and native groups now hope for a ruling that will do the same for forestry. "The preferable course is not to litigate, but to negotiate," said Baker.

\section{Urban Forestry News / Nouvelles dans le domaine de la foresterie urbaine \\ Ministery Enacts Compensation Regulations to Aid in Tree-replanting Efforts}

The Ministery of Agriculture and Agri-Food Canada responsible for the Canadian Food Inspection Agency, announced in mid-May, the implementation of the Introduced Forest Pest Compensation Regulations to compensate property owners in Ontario and Nova Scotia for the replacement of trees ordered destroyed to control the spread of three invasive forest pests.

The Canadian Food Inspection Agency (CFIA) estimates the replanting effort will cost approximately $\$ 6.5$ million.

Compensation will be available to property owners whose trees were ordered destroyed due to measures used to combat the the Brown Spruce Longhorn Beetle (BSLB) in Halifax, Nova Scotia, the Asian Long-horned Beetle (AHLB) in parts of Toronto and Vaughan, Ontario and the Emerald Ash Borer (EAB) in Essex County and parts of the Municipality of Chatham-Kent, Ontario.

Three categories of land have been established as the basis for providing compensation: privately-owned, public or municipal lands and woodlots.

Compensation is to be provided over the coming months on the basis of the direct cost of replacing a tree up to a set maximum amount. The maximum amounts are $\$ 300$ per tree ordered destroyed on privately-owned land, $\$ 150$ per tree on public land, and $\$ 40$ per tree in woodlots. The maximum amount will apply to both the purchase of a tree and to reasonable costs for planting. The CFIA is establishing an administrative process over the next months to reimburse those affected in each region. The regulations exclude certain lands from compensation, such as railway and utility right of ways, drainage ditches and unmanaged or wild areas.

The CFIA has carried out an aggressive eradication campaign, resulting in the removal of over 137,000 trees to date. The Agency is working with federal, provincial and local agencies to protect Canada's trees and forests by stopping the spread of these destructive pests.

For more information on these forest pests and movement restrictions in place for wood and nursery stock in these regulated areas, please see our website at www.inspection.gc.ca. 